\title{
Do Entry Form Waivers Properly Inform Triathlon Participants of the Dangers of the Sport?
}

\author{
Gina Pauline, Barbara Osborne, and John J. Miller
}

\begin{abstract}
A growing number of triathlete fatalities and serious injuries over the past ten years have raised concerns regarding the safety of participation as well as the event's responsibility in properly informing the participant of the risks involved in the sport. The purpose of this research was to determine whether participants were properly informed of the risk of competing in triathlon events. Specific research questions include 1) What clauses were included in triathlon waivers? 2) Who is protected from liability? 3) Are risks of participation properly communicated to establish informed consent? Content analysis of the participation waivers of 84 competitive triathlons in the United States was used to identify the various clauses present. The findings show that the majority of the waivers did not use well-crafted waivers that clearly described the myriad of risks posed by triathlon participation. Additional findings and implications relevant to the aforementioned research questions will be discussed.
\end{abstract}

Endurance sports, particularly triathlons, have gained in popularity in the United States. According to USA Triathlon, more than 4,300 events are sanctioned at varying levels of competition (e.g., duathalons, triathlons, senior, youth) (USA Triathlon, 2014). The term sanction refers to the compliance of a multisport event to USA Triathlon's safety requirements. Safety plans, course maps, and event details must be submitted for review (USA Triathlon, 2014). Furthermore, USA Triathlon (2014) noted, "annual memberships increased 5.5 percent from year-end 2012 to year-end 2013, growing from 165,698 to 174,787 and ranks as the third-highest growth percentage in the past five years. The number of total youth members increased to 57,846 in 2013 from 51,585 in 2012, a jump of 12.1 percent." A staggering 2.3 million individuals completed a triathlon in 2011(USA Triathlon, 2014). The growth is also apparent as the NCAA approved triathlon as the next emerging sport for women in 2014 (USA Triathlon, 2014A). At the international level, the sport is the fastest growing of the U.S. Olympic movement (USA Triathlon, 2014). Triathlon was added to the Olympic program in 1994 and made its debut at the 2000 Olympic Games in Sydney, Australia (USA Triathlon, 2014A).

Pauline is with the Dept. of Sport Management, Syracuse University. Osborne is with the Dept. of Exercise and Sport Science, University of North Carolina. Miller is with the College of Health and Human Services, Troy University. Pauline (gapaulin@syr.edu) is corresponding author. 
It is important to recognize the physical demands and rigor of participating in a triathlon on the individual. Research has shown that there are certain inherent risks including: dehydration, muscle cramping, heat illness, musculoskeletal injuries and trauma that may occur while competing in a triathlon (Harris, Henry, Rohman, Haas, \& Maron, 2010). In addition to the physical challenge and risks of competing in three sports (swimming, bicycling, and running) consecutively within one race, it is important to note the environmental conditions that may present themselves in the course of an event (Dallam, Jonas, \& Miller, 2005). The risks not only come from the course conditions but also merely from the nature of the sport as it is inherently dangerous for both the participants as well as nonparticipants (e.g., volunteers, spectators, officials) (Miller, Pauline, \& Wendt, 2014).

Given the increase in participation, as well as the nature of the risks involved, the sport has seen a trend of increases in not only injuries but also fatalities. Based on the growing concerns, USA Triathlon sanctioned a study to look at not only the number but the causes of such incidents. From 2003 to 2011 there were 44 athlete fatalities (Creswell, 2013). The deaths cannot be pinpointed to a given age category nor race distance; however, 39 of the 44 fatalities were attributed to sudden cardiac death (Creswell, 2013). Furthermore, the majority of the deaths occurred during or immediately following the swim segment. The sport has continued to witness fatalities as in 2013 there were an additional 10 reported deaths at various segments of the triathlon event (Creswell, 2013). The 2013 Ironman South Africa 70.3 experienced deaths of two male participants, ages 29 and 37, both during the swim leg despite having no history of cardiac problems before the race (Triathlete. com, 2103).

In the United States, in 2013, on the 10th anniversary of Musselman triathlon in Geneva, New York, two deaths occurred during the bike portion in two separate event distances (sprint and half ironman) (Collinsworth, 2013). In 2014, in the United States there were at least two deaths, both during the swimming portion (Ford, 2014). The sport also saw deaths in other countries, including one in Australia in which a healthy 21 year old male died during the swim segment (Calligeros, 2014). In a recent study, triathlon race directors reported that the majority of participants over a three-year span required significant medical attention (Miller et al., 2014). The primary injuries that required such attention included broken bones, heat exhaustion, dehydration, and hypothermia. Finally, eight $(18 \%)$ respondents revealed that at least one participant had died competing in their triathlon over the past three years (Miller et al., 2014).

In light of the recent events, there have also been at least three lawsuits filed against the event organizers for unsafe race conditions, negligence in safety measures, as well as lack of safety personnel. In 2006, a triathlete, Bernard Rice, died during the swimming portion of the Ironman Florida competition. In 2009, a representative of Rice's family sued North America Sports, Inc., USA Triathlon, Inc., and World Triathlon, Inc., alleging that Rice's death was the result of negligence in conducting the triathlon (Moore v. North American Sports, 2008). The complaint asserted that the triathlon was conducted negligently by failing to

1. Appropriately oversee, guard, monitor, or secure the swim area and swimmers, including but not limited to the decedent;

2. Suitably organize the swim competition in a reasonably safe manner; 
3. Have proper procedures or rules governing response to emergency situations, including drownings

4. Provide enough supervision at the swim competition event;

5. Provide enough lifeguards or other persons trained in first aid or cardiopulmonary resuscitation for the number of participants in the triathlon;

6. Adequately analyze the oceanic and weather conditions to make certain the conditions were safe for swimmers such as the plaintiff;

7. Suitably provide adequate safety equipment, safety floatation equipment and life-saving equipment to aid in rescue efforts;

8. Possess a risk management program;

9. Call off the competition when the conditions were such as to make it safe to continue. (Moore, 2008)

The defense provided evidence that Rice suffered a massive heart attack that was so severe that no able assistance would have saved him (Moore, 2008). The presentation of this evidence was satisfactory for the federal court jury not to hold the organizers of the Ironman triathlon liable for Rice's death (Moore, 2008).

Another lawsuit, Schmidt v. Midwest Sports Events, Inc. (2010), alleged that a triathlon organization as well as the event director was negligent by failing to train lifeguards or provide adequate emergency care. According to the allegations in Schmidt, Midwest Sports Events increased risk and danger for participants competing in the triathlon by stressing that the entrants did not need to be experienced or physically fit athletes (Schmidt v. Midwest Sports Events, Inc., 2010). At roughly 8:00 a.m., Schmidt was found floating in water (Schmidt v. Midwest Sports Events, Inc., 2010). She was taken to the shore where CPR was administered yet it was reported that it took a while for the EMS to arrive and there was no reported AED at the race site. The victim later died at the hospital. The parties in the lawsuit agreed to a settlement of $\$ 110,000$ to be paid by the sanctioning organization, Midwest Sports Events, Inc. (Schmidt v. Midwest Sports Events, Inc., 2012). Disturbingly, Schmidt was the third death during the 2009 Wisconsin triathlon season as Daniel Murry, 33, died during the swim of the Pewaukee Triathlon, and Julie Silletti, 54, died during the swim of the Elkhart Lake Triathlon (Haggerty \& Held, 2009).

More recently, Cheryl Angelo, the spouse of Richard Angelo, filed suit against USA Triathlon after the husband died during the national championship event in Vermont in 2012 (Angelo v. USA Triathlon, 2014). Angelo was an avid athlete, and had participated in 15 triathlons before this one. Angelo died during the swim segment of the race. The complaint stated that USA Triathlon was negligent in organizing the event, failed to provide adequate supervision at the swim, didn't have enough lifeguards or other trained staff on hand, and did not have adequate lifesaving equipment. The complaint also noted that due to the high waves and sun, the swim conditions were hazardous (Angelo v. USA Triathlon, 2014).

As the sport continues to grow in popularity and more events are held, it can be anticipated that there will be further injuries, fatalities, and litigation. However, little research has been conducted to specifically identify how triathlon event managers deal with managing potential risks unique to the triathlon setting. In a study involving the risk management of triathlons, Miller, Pauline, and Wendt (2014) reported that the majority of triathlon race directors indicated that the participants 
had to complete and turn in a waiver before competing in a triathlon. Because a waiver serves as a contractual agreement between two parties where the opportunity to participate is exchanged for a promise not to sue, it may serve as a significant deterrent against potential legal action (Cotten, 2007; Miller, Young, \& Martin, 2009). An effective waiver must clearly communicate the risks involved in the activity and that it is the participant who waives his or her right to sue the triathlon organizer for injuries caused by ordinary negligence. In McDonald $v$. Whitewater Challengers (2015), the court stated that the language in the waiver must specifically state the intention of the parties beyond doubt. Thus, correctly used, a waiver should communicate the potential risks as well as the transfer of liability to the participants. Such communication of risks and liabilities permits the participants to make an informed decision regarding their involvement in an event (Reynolds \& Seeger, 2005). As such, it is important to understand how a waiver may be used as a contractual defense in a lawsuit.

\section{Requirements for a Legal Contract}

Because a liability waiver is a contract between the event organizer and the participant that alters their rights and responsibilities under tort law, it is extremely important that the participant understand what is being consented to and what rights he or she is giving up (Grieshop Corrada, 2006). In general, the elements of a legally enforceable contract are offer, acceptance, consideration, and capacity. It may be difficult to ascertain the validity or enforceability of an entry form waiver on its face, as the law of contracts is determined by state law. Each state's statutes or common law precedent may be different depending on the type of activity, whether the participant is a minor or adult, whether the participant understands the risks related to participation, and/or whether a participant can waive the rights of the beneficiaries of his/her estate in case of death (Cotten, 2007; Grieshop Corrada, 2006). This section will introduce some of the fundamental legal concepts related to contracts and participant liability waivers: properly identifying the parties, consideration, capacity, and understanding the intent of the parties through use of clear, unambiguous language. Whether courts will enforce participant liability waivers as a matter of public policy is also introduced.

\section{The Parties}

According to Barron's Law Dictionary (1991), a party is a person or entity who enters into a contract. In this study, the triathlon organizer and the triathlon participant are the parties to the contract. There may also be third-party beneficiaries, such as sponsors or volunteers, who are protected from liability by the contract, as well as other third parties, such as family members, who are barred from redress under the terms of the agreement. In situations when both parties do not sign the document, the contract is enforceable against the party that signs it. In a participant waiver situation, only the participant signs the entry form document, allowing the event organizer to enforce the waiver.

In general, the common law doctrine of privity of contract prevents a contract from providing rights or imposing obligations on anyone other than the parties to the contract (Black's Law Dictionary, 1991). Often, waivers include language that bars 
others, such as the participant's spouse, heirs, estate, and/or assigns from making claims against the triathlon organizer for the participant's injuries or death. This language, which waives the rights of others who are not a party to the contract, may or may not be valid depending upon the law of the state that the triathlon is conducted (Coughlin v. T.M.H. International Attractions, Inc., 1995; Schoeps v. Whitewater Adventures LLC, 2005). For wrongful death, the majority of states hold that claims of "heirs or an estate are only valid if the participant would have had a valid claim" (Cotten, 1996, p. 118). For example, in Espinoza Jr. v. Arkansas Valley Adventures (2014), a woman signed the required participant waiver before embarking on a rafting trip. The raft capsized and she was entangled in tree branches and drowned. The court stated:

To prove a wrongful death claim, an heir must establish that (1) the death of the decedent; (2) was caused by a wrongful act and (3) that the decedent would have been able to maintain an action for injuries, had the person survived" (Espinoza Jr. v. Arkansas Valley Adventures, 2014, p.6).

The court rejected the wrongful death claim made by her heir because the woman would have been barred from bringing forward any claim for injury based on the exculpatory language in the participant waiver (Espinoza Jr. v. Arkansas Valley Adventures, 2014, p.22). However, other states such as California hold that a wrongful death claim is not derivative of the decedent's claims, but is a new cause of action based on the heirs own independent injury because of the death of a relative. In these states, a waiver of liability executed by the decedent would not necessarily bar a subsequent wrongful death action by the heirs (Eriksson $v$. Nunnink, 2015). This creates a legal distinction between the ineffectiveness of a preinjury release of heirs' rights to assert wrongful death claims and the effectiveness of a release of liability for negligence claims on behalf of the participant (Eriksson v. Nunnink, 2015).

Third parties, such as triathlon sponsors and public facilities where the triathlon is conducted, are often named as third party beneficiaries in the participant waiver. It is important that any party expecting to be protected from liability be properly named as a party in the waiver because of privity of contract (Grieshop Corrada, 2006). The event organizing-entity, employees of the organization, volunteers, and sponsors for the event, as well as other event participants, are typically listed in the waiver (Cotten, 1996; Grieshop Corrada, 2006). The issue of whether a party was properly named in the participant waiver has been addressed in numerous cases.

According to the Court of Appeal of California in Lashley v. East County Gymnastics (2001), the defendant gymnasium was expressly and unambiguously listed in the participant waiver signed by the injured minor's parent and thus was not a third party beneficiary, but a properly named party to the agreement. The gymnasium was therefore released from liability for injury resulting from participation in any way in respondent's gymnastics program and use of its facility (Lashley $v$. East County Gymnastics, 2001).

Where a waiver fails to expressly mention a party or includes general encompassing terms, there may not be a sufficiently clear indication of intent for an entity to be a beneficiary of the agreement. In Amburgey v. Atomic Ski USA, Inc. (2007), the U.S. District Court held that Atomic, the manufacturer of ski equipment rented to customers at Sunday River by Crisports Ski Shop, was not a signatory to the release form in which the corporation was not expressly listed. The form included 
only a single vague mention of releasing "distributors" from any "alleged negligence," such that a customer would be led to understand "distributor to mean the ski resort or rental shop, not the equipment manufacturer (Amburgey v. Atomic Ski USA Inc., 2007, p. 28). It failed to include any indication that agreement by the customer waived a claim of manufacturing or design defects against Atomic and thus did not clearly intend Atomic as a protected party under the contract (Amburgey v. Atomic Ski USA, Inc., 2007).

Similarly, in Kolosnitsyn v. Crystal Mountain, Inc. (2009), release of "providers" or "owners" from liability in the waiver signed by the plaintiff at the rental shop while renting his ski equipment was ambiguous in that it was unclear whether those terms could be interpreted "objectively and conspicuously" to include the ski resort itself (p. 9-10). Since some ski resorts contract out services to private rental companies, it was not clear whether the language of the waiver released liability for injuries related solely to the equipment rental or also for use of the ski area itself. Because of the ambiguity, the court held that the waiver did not shield Crystal Mt. from liability (Kolosnitsyn v. Crystal Mountain, Inc., 2009).

It is important for all parties who risk liability to be clearly identified as parties in the participant waiver. Otherwise, those not named as parties should be sufficiently identified as third party beneficiaries to be protected. In Palmer v. Lakeside Wellness Center (2011), Palmer stepped onto a treadmill that was moving and was thrown off and injured when she fell into an elliptical machine. Palmer stated that the treadmill's control panel looked like it was off. The equipment manufacturer, Precor, tried to assert the participant waiver as a defense for liability. The contract that Palmer had signed stated that she agreed " to fully and forever release and discharge Lakeside and affiliates and their respective officers, directors, employees, agents, successors and assigns, and each of them from any and all claims, damages, rights of action or causes of action" (Palmer v. Lakeside Wellness Center, 2011, p. 782-783). The Nebraska Supreme Court found that Precor was not explicitly identified in the waiver and there was no other evidence that the manufacturer was an intended third party beneficiary. In determining that Precor was not shielded from liability as a result of Palmer's waiver, the court stated: "The right of a third party benefited by a contract to sue thereon must affirmatively appear from the language of the instrument when properly interpreted or construed" (Palmer v. Lakeside Wellness Center, 2011, p. 785).

\section{Consideration}

In contract law, consideration is the bargained-for exchange between the parties, or the inducement that is generally required to make a promise binding and a contract enforceable (Barron's Law Dictionary, 1991). While in ordinary contract law, a waiver normally is effective without proof of consideration (Cabinetree of Wisconsin v. Kraftmaid Cabinetry, 1995), for participant waivers, consideration is typically met if the waiver states: In consideration for my participation in (name of event), I agree to relieve the (event organizer) of liability for injury due to ordinary negligence (Cotten, 1996). In Last v. Quail Valley Country Club (2010) the court determined the releaser receives the benefit of participation, a legal right to "do that which he would not otherwise be entitled"-participation was the consideration (p. 22). Similarly, in Mero v. City Segway Tours of Washington, DC (2013), 
the court found that the plaintiff's promise he would not sue the defendant for negligence if he were injured, and the defendant's provision of a Segway to the plaintiff for the tour was sufficient consideration for the agreement to be binding. The aforementioned statement indicates that the exchange of the triathlete's right to sue the triathlon organizer for the right to participate is sufficient to be legal consideration for an enforceable contract. However, some states have held that there must be more than just general awareness of danger posed by participating in the event; valid consideration requires that the participant fully contemplate the risks involved before signing the waiver (Cotten, 2007). For example, in Wycoff $v$. Grace Community Church of the Assemblies of God (2010), the Colorado appellate court held that the participant wavier did not provide adequate consideration as it did not adequately warn or inform of the risks of the activity.

According to Kathy Matejka, safety event services director for USA Triathlon, "The fact is triathlons are inherently dangerous" (Held, 2009, para. 22). Research indicates that triathlon participants may not be aware of the risks inherent in the sport. Many participants do not consider the differences in training conditions as compared with race conditions. For example, all sanctioned triathlons take place in an open body of water (e.g., lake, ocean). However triathlon participants may train in chlorinated swimming pools, in conditions where they might be the only one in the lane, and they can see the bottom of the pool clearly (Miller et al., 2014). Triathletes may be completely unaware of their potential fear of open water when they realize the depth as well as the difference in the water quality. Similarly, triathletes start the swim en masse or by age group with 50 people to 2,500 people charging into the water at the same time. While it is foreseeable that injuries may occur through contact with other participants, a novice triathlete may not understand the risks inherent in that situation based on his or her training experience.

There are also inherent risks in triathlon related to the participant's personal health and fitness to compete. Research indicates that not all triathletes are physically fit, well-conditioned, and experienced (Marron, Araujo, Thompson, Fletcher, de Luna, Fleg, \& Bazzare, 2001). Those that are unprepared as a result of limited experience and low fitness level may not be aware of the increased risk of injury due to an elevated cardiovascular response and failing to adequately replace fluids resulting in dehydration (Dallam, Jonas, \& Miller, 2005).

Although a waiver may be valid in some states using broad language that includes "all risks inherent in the activity," other states require delineation of the risks inherent in the activity to prove which risks are known and therefore waived (see Coughlin v. T.M.H. International Attractions, Inc., 1995). Triathlon continues to grow in popularity and more events are organized, making it likely many participants are novice triathletes. While event managers cannot guarantee injuries or deaths to participants will not occur during an event (Miller et al., 2014), they can ensure that the participation waiver fully enumerates the risks of competing in a triathlon. It may appear obvious that triathlon participation is inherently dangerous, but large disparity in the level of fitness, experience, and understanding of the risks among participants necessitates a participant waiver that enumerates the risks inherent in triathlon participation (see Conning v. Dietrich, 2011; Hague v. Summit Acres Skilled Nursing \& Rehabilitation, 2010). If a waiver is too general, it cannot alert a voluntary participant of the risks and therefore may not be enforceable. 


\section{Capacity}

A party must have the "mental ability to make a rational decision which includes the ability to perceive and appreciate the relevant facts" to have the capacity to contract (Barron's Law Dictionary, 1991). Capacity, usually examined by addressing mental competence, sobriety, or age (for minors), is another factor that impacts a contract's validity and enforceability. In many contracts, a simple statement such as, "I warrant that I have full legal capacity to execute this agreement," may be included just before the signatory line. While some may question the sanity of anyone who voluntarily chooses to participate in a triathlon event at any distance, this study was not concerned with measuring issues related to the participant's capacity to contract.

\section{Language}

The words used in any contract are important in that the parties must understand the meaning and intend to agree. For these reasons, courts will generally look to the plain and ordinary meaning of the words within the document, without reference to other materials. In Sa v. Red Frog Events, LLC (2013), the U.S. District Court dismissed a claim of ordinary negligence against the company that presented the Warrior Dash, an extreme 5k obstacle race. The participant, James Sa, was injured when he dove head first into a mud pit. The Warrior Dash entry form specifically stated that participants agree "to not dive into or enter the mud pit head first" ( $S a$, 2013 , p. 4). While the participant waiver was upheld for the ordinary negligence claim, allegations of gross negligence or willful and wanton misconduct were allowed to proceed, as there was evidence that a race announcer was standing by the mud pit encouraging participants to dive in.

Ideally, the words used should be straightforward, unambiguous, and comprehendible; courts have generally disfavored documents that use confusing "legalese" (Hanks v. Powder Ridge Restaurant Corp., 2005). According to Hanks (2005),

[T] his does not imply that only simple or monosyllabic language can be used in such clauses. Rather, what the law demands is that such provisions be clear and coherent... The question is whether "an ordinary person of reasonable intelligence would understand that, by signing the agreement, he or she was releasing the defendants from liability for their future negligence. (p. 324-325)

In Okura v. U.S. Cycling Federation (1986), event management was not responsible for injuries suffered by a participant because the waiver language on the entry form was clear, legible, and "not buried in a lengthy document or hidden among other verbiage" (p. 1468). Similarly, a document that printed the word "negligence" in bold and all capital letters, several times, was sufficiently clear to be enforceable (Hanks v. Powder Ridge Restaurant Corp., 2005). However, in Lewis v. Habitat for Humanity of Greater New Haven, Inc. (2012), the Connecticut Superior Court found that the exculpatory agreement used in a cross-country cycling event was not sufficiently clear to waive the liability for injuries suffered by participants. The court in Lewis concluded that the text in the waiver was unclear because: 1) there were extremely long sentences of multiple interrelated clauses; 2) the language was not conspicuous; 3) no attempt was made to set the word negligence off from the rest 
of the text; 4) no headings or markers were used in the two-page document. Thus, a participant waiver that is communicated in a clear, unambiguous, and explicit fashion is more likely to be upheld (Buchan v. U.S. Cycling Federation, 1991).

\section{Use of "Negligence"}

Specific use of the word "negligence" may clarify the intent and understanding of the parties. Some state courts have held that if the service provider wants to be indemnified against negligence, it has to specifically and clearly state that in the waiver (Roer v. 150 West End Avenue Owners Corp., 2010; Wycoff, 2010). The Restatement (Second) of Contracts, states that "[1]anguage inserted by a party in an agreement for the purpose of exempting him from liability for negligent conduct is scrutinized with particular care and a court may require specific and conspicuous reference to negligence under the general principle that language is interpreted against the draftsman.” (\$195, comment (b), 1981). In Hyson v. White Water Mountain Resorts of Connecticut, Inc. (2003), the court held that it could not enforce an exculpatory agreement because it only referred to the risks involved in the activity, but made no specific reference to harms caused by the negligence of the service provider (p. 643).

The majority of states have indicated that the word negligence is not necessary as long as the words used in the participant waiver are sufficient to show the intent of the parties. In Henderson v. Quest Expeditions (2005), the court stated that as long as the intent to eliminate liability is apparent, the absence of the word "negligence" is not fatal (p. 12-13). The proximity of the participant's signature to the exculpatory clause can also be an expression of the intent of the parties. An exculpatory statement that is not on the same page as the signature could be interpreted as intent to conceal the purpose of the clause (Cotten, 1996; Grieshop Corrada, 2006; Kubisen v. Chicago Health Clubs, 1979). Ideally, the statement that the participant has read the agreement and understands the terms and conditions should be adjacent to the signature (Cotten, 1996).

\section{Public Policy}

It is generally agreed that liability waivers must not violate public policy, although states disagree as to whether preactivity waivers of liability actually violate public policy (Berlangieri v. Running Elk Corp., 2003; Lewis v. Habitat for Humanity of Greater New Haven, 2012). The term "public policy" can be defined as "the principle of law that holds no citizen can lawfully do that which has a tendency to be injurious to the public or against the public good" (Black's Law Dictionary, 1991). Typically, a participant liability waiver is considered a private, voluntary contract that shifts the liability that would normally be placed on the triathlon event provider to the triathlon participant (Banfield v. Louis, 1991). Because participation in the activity is voluntary, shifting the liability from the service provider to the participant is not generally adverse to public policy in the majority of states (Greer, 2011). However, Greer (2011) argues that event organizers have a duty to provide a reasonably safe participation experience, and should be liable for their own acts that increase the risk of harm to participants beyond those dangers that are inherent in the sport. Because assumption of risk is an adequate defense for event organizers, waivers for ordinary negligence should be void against public policy (Greer, 2011). 
In Wisconsin, liability waivers are generally disapproved as freedom to contract is outweighed by the need for the service provider to adhere to a duty of care (Grieshop Corrada, 2006). The Wisconsin Supreme Court decision in Atkins v. Swimwest Family Fitness Center (2005) is illustrative:

We conclude that the exculpatory language in Swimwest's form is unenforceable, since it is contrary to public policy. The waiver of liability language is, first, overly broad and all-inclusive. The use of the word "fault" on the form did not make clear to Wilson that she was releasing others from intentional, as well as negligent, acts. Second, the form served two purposes, guest registration and waiver of liability for "fault," and thus failed to highlight the waiver, making it uncertain whether Wilson was fully notified about the nature and significance of the document she signed. Finally, Wilson did not have any opportunity to bargain. If she had decided not to sign the guest registration and waiver form, she would not have been allowed to swim. The lack of such opportunity is also contrary to public policy. (p. 2)

In Connecticut, the courts support the principle that parties are free to contract for whatever terms they agree, but will also render a contract unenforceable if it violates public policy (Hanks, 2005). Many states have adopted the six-factor test established in Tunkl v. Regents of the University of California (1963) to determine whether an exculpatory agreement violates public policy. The six factors include

1. The agreement concerns a business generally suitable for public regulation.

2. The service provider performs a service of great importance to the public.

3 . The provider is generally willing to perform the service for any member of the public who seeks it.

4. The service provider has a decisive advantage in bargaining strength against the members of the public who seek the services.

5. The agreement is a standardized adhesion contract of exculpation that does not provide the participant with an opportunity to obtain protection against negligence.

6. The participant is under the control of the service provider and subject to risk of carelessness by him or his agents. (Tunkl, 1963, p. 328)

While the Tunkl factors are influential, they are not dispositive, and states may also consider a number of other relevant factors to determine what constitutes the public interest (Lewis, 2012).

In Lewis v. Habitat for Humanity of Greater New Haven, Inc. (2012), the court weighs whether exculpatory clauses undermine the public policy considerations of the tort compensation system:

[T] he fundamental policy purposes of the tort compensation system [are] compensation of innocent parties, shifting the loss to responsible parties or distributing it among appropriate entities, and deterrence of wrongful conduct ... It is sometimes said that compensation for losses is the primary function of tort law ... [but it] is perhaps more accurate to describe the primary function as one of determining when compensation [is] required. An equally compelling 
function of the tort system is the prophylactic factor of preventing future harm ... The courts are concerned not only with compensation of the victim, but with admonition of the wrongdoer. (p. 12)

In holding that the participant liability waiver was unenforceable as a matter of public policy, the court emphasized that event organizers are in the best position to protect participants from harm, should not be allowed to skirt the duty to manage the event in a safe way, and are best able to assume the risk of negligence through proper insurance (Lewis, 2012). In addition, the event in this case was a cross-country cycling ride to raise funds for a charity, therefore "Placing the burden of the defendant's potential negligent conduct on the individual participants who are attempting to contribute to a charitable cause flies in the face of current societal expectations" (Lewis, 2012, p. 7). The court ultimately concludes that "event organizers should not be exculpated from their potential negligence, which will allow them to receive all the benefits of participant fund-raising but bear none of the risks of their own actions" (Lewis, 2012, p. 8).

In summary, state law governs the enforceability of participation waivers. While some elements of a valid contract-identifying the parties, consideration, and capacity - are fairly uniform, and there is significant variability by state in determining who holds rights, who can waive rights, interpreting intent, and whether liability should be shifted from the event manager to the participant as a matter of public policy. While waivers may be useful, to varying degrees, to protect event managers from liability for ordinary negligence, they are generally not effective for acts of gross negligence, recklessness, or intentional torts.

\section{Purpose of the Study}

The purpose of this research is to determine whether participants are properly informed of the risk of competing in triathlon events. Specific research questions include

- What clauses are included in triathlon waivers?

- Who is protected from liability and whose rights are waived?

- Are risks of participation properly communicated to establish informed consent?

This study is the first to systematically analyze the legal components of participant waivers specifically for triathlons. It is significant as it provides information for triathlon event managers to identify weaknesses in current participant waivers. Waivers that better inform participants of the risks allow them to make more informed decisions about assuming the risks inherent in triathlon participation, perhaps reducing deaths and injuries related to physical readiness. Ideally, better informed triathletes will reduce the harm suffered due to their own physical limitations. A better informed participant should also reduce the potential liability for event managers by strengthening assumption of risk, contributory negligence, and/or comparative negligence defenses by clearly establishing what the participant knew or should have known before engaging in the activity. When both the triathlon organizers and the participants are more careful, fewer injuries and less litigation should result. 


\section{Methodology}

The research methodology for this study used content analysis of triathlon waivers. "Content analysis is a research technique frequently used for examining information, or content, in written or symbolic material" (Young, 2001). Content analysis has been successfully used in previous studies involving analysis of contracts (see Rustad, Buckingham, D'Angelo, \& Durlacher, 2012). As this study required the review of multiple participant waivers, content analysis was chosen as the appropriate method for data identification and analysis.

The population was defined as sanctioned competitive triathlons in the United States. The sample used in this study was limited to those triathlons that had websites with entry forms and waivers on-line. Eighty-four triathlons (84) met this criteria, and the waivers provided on the triathlon websites were uploaded.

Content analysis requires development of a systematic, replicable method of coding to reduce complex qualitative information to specific quantitative indicators (Andrew, Pedersen, \& McEvoy, 2011). Initial codes were developed a priori from knowledge of contract construction and participant waivers (DeCuir-Gunby, Marshall, \& McCulloch, 2011). Secondary sources, such as Cotten's Guidelines for Writing or Evaluating Exculpatory Agreements (1996) and law review articles, as well as case precedent represented in the literature review also influenced the initial codebook. Each waiver was coded for the type of clauses it contained, the parties protected from liability, and to determine whether the risks of participation were properly communicated. The researchers also engaged in open coding; subcodes were added within the three primary categories as new concepts were found in the documents (DeCuir-Gunby, Marshall, \& McCulloch, 2010). The completed codebook contained a code mnemonic and definition of the inclusion and exclusion criterial to explain how the code differed from others (Macqueen, McLellan, Kay, $\&$ Milstein, 1998). By reviewing and coding the waivers used by these triathlons, the type of information present in each contract was identified and organized in an Excel spreadsheet. Seventeen (17) different clauses were identified in coding. Two coders independently reviewed all 84 triathlon waivers. The consistency of the coding was measured by comparing the results of the two code books; reliability was established at $100 \%$ consistency.

\section{Results and Discussion}

\section{Research Question 1: What Clauses are Included in Triathlon Waivers?}

Content analysis revealed significant variation in the content and the specific clauses included in the 84 waivers from competitive triathlons in the United States. A total of 17 general clauses were identified and analyzed. The code for each of the clauses, frequency, and percentage is reported in Table 1. Of the 17 identified clauses, four identify and define the parties to the contract (both those waiving rights and those who are relieved of legal responsibility), four address risks, five clarify the intent of the parties, and the remaining four clauses were generally related to contract construction such as defining negligence, indemnification, severability, and jurisdiction. 


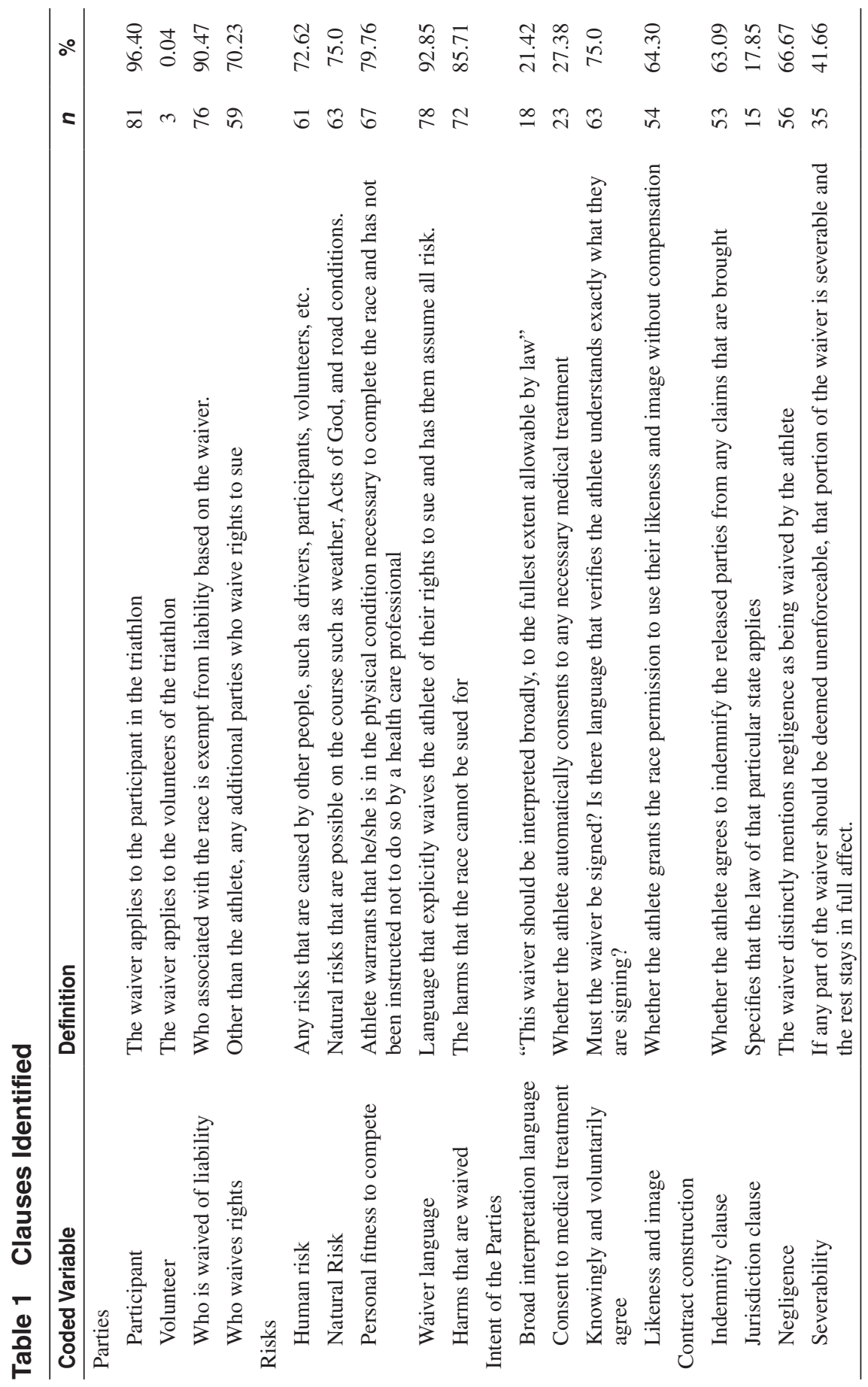


The overall identification of the various clauses included in triathlon participant waivers showed that very few of these documents are well drafted. The intent of the document is not clear in almost $20 \%$ of the waivers. Almost a third of the documents failed to mention that the participant is specifically waiving the triathlon organizer of liability for negligence. Less than half of the waivers included a severability clause: this appears as if it would be an essential clause to be incorporated, as the poor overall waiver construction could likely deem parts of the contract unenforceable. Including a jurisdiction clause is also widely recommended in contract construction. Perhaps the 69 triathlons that did not include a jurisdiction clause believe that their waiver will keep them out of any court.

One particularly surprising comparison was found in the "Intent of the Parties" section. A majority of triathlons $(64.30 \%)$ chose to include a likeness and image waiver clause in the document, giving the event permission to use the triathlete's likeness and image in association with the event without compensating the participant. This assures that the event can use photos and videos of the event in its marketing and promotional materials and/or websites, reduce its costs, and perhaps increase its profitability. However, less than a third of the triathlons $(30.95 \%)$ included a statement that automatically authorizes necessary medical treatment. It is possible that triathlon organizers chose not to include an automatic medical consent clause because they do not want to imply that they will provide treatment. Yet failure to provide medical care in an event as dangerous as a triathlon could be perceived as gross negligence or recklessness given the obvious foreseeability of injuries. Acts of this nature would not be protected by a waiver that protects against claims of ordinary negligence. In addition, because a contract is enforceable against the party that signed the contract and entry form waivers are only signed by the participant, it is unlikely that the triathlon organizer could be held accountable to provide medical services by mentioning that in the waiver. As a document that shifts liability from the triathlon manager to the participant, a medical consent clause appears to be a much more important clause to include, given the high likelihood of any kind of physical injury, from blisters to unconsciousness or death.

\section{Research Question 2: Who is Protected From Liability and Whose Rights are Waived?}

Overall, only $76(90.47 \%)$ of the waivers named parties that were expressly waived from liability. While one might expect this number to be $100 \%$, without proper identification of the parties the court may conclude that the waiver is not a valid contract. It is also possible that the documents that did not identify parties waived from liability are from triathlons conducted in states that do not allow waivers as a violation of public policy.

Further analysis of these clauses identified twelve unique parties which were coded to determine who was protected from liability by the waiver. The corporate entity/race organization was the most frequently identified party protected from liability: $87 \%$ of all waivers included this. Sponsors (69\%), the government (i.e., state, city, or municipality) $(58 \%)$, and volunteers $(54 \%)$ were the only other identified parties that were protected from liability in over half of the waivers. Triathlon organizers were apparently not concerned about protecting coparticipants from liability, as only three waivers $(.04 \%)$ noted them, even though the 
likelihood of being injured due to contact with a coparticipant is quite common (see Moser v. Ratinoff, 2003). Table 2 identifies the various parties coded as waived of liability, as well as the frequency and percentage these parties were identified in the waivers.

It is assumed that the triathlete/participant is the party giving up his or her rights as communicated in the waiver because he or she is the person signing the document. However, three of the 84 waivers did not expressly identify the participant. In addition, $70.23 \%(n=59)$ of the waivers also included a clause that waived the rights of parties other than the triathlete to sue. Generally, under contract law a party may only waive his or her own rights. Further analysis of these clauses identified 15 different parties that were coded as giving up rights in the triathlon participation waiver; these parties are listed in Table 3. Generally, these categories name family members and others who would have a legal claim for wrongful death or an interest in representing the estate of a deceased participant. For the majority of states, heirs or executors of an estate would only be able to bring a negligence claim against the triathlon operator if the participant would have had the right to file a claim (i.e., Ariz. Rev. Stat. §12-611, 2014). However, in some states, actions for loss of consortium or wrongful death are rights of the surviving spouse and/or heirs which are independent of the rights of the deceased participant (i.e., Conn. Rev. Stat. Ann. §52-555 and §52-555a, 2014). From a risk management perspective, triathlon organizers should include a waiver of rights for spouse, heirs, and/or the estate which would at minimum discourage claims; in states that only allow a survivor's claim to go forward if the participant would have had a valid cause of action, the waiver would invalidate that claim. However, if the participant is to knowingly waive the rights of survivors, this clause should be written in a way that clearly states the rights that the participant waives.

Table 2 Parties Identified Who Waive the Right to Sue

\begin{tabular}{lcc}
\hline Coded Variable & $\boldsymbol{n}$ & $\%$ \\
\hline Corporate entity/race organization & 73 & 86.9 \\
Sponsors & 58 & 69.0 \\
State, Government, City, municipalities & 49 & 58.3 \\
Volunteers & 45 & 53.6 \\
Employees & 40 & 47.6 \\
Agents & 34 & 40.4 \\
Miscellaneous & 21 & 25.0 \\
Insurance provider & 20 & 23.8 \\
Independent contractors & 18 & 21.4 \\
Property owners & 15 & 17.8 \\
Other race participants & 3 & 0.03 \\
Equipment manufacturers and suppliers & 0 & 0.00 \\
\hline
\end{tabular}


Table 3 Parties Identified Who Waive the Right to Sue

\begin{tabular}{lcc}
\hline Coded Variable & $\boldsymbol{n}$ & $\%$ \\
\hline Participant & 75 & 89.2 \\
Heirs & 39 & 46.4 \\
Administrators & 39 & 46.4 \\
Executors & 38 & 45.2 \\
Successors & 31 & 36.9 \\
Next of kin & 29 & 34.5 \\
Guardian & 19 & 22.6 \\
Parents & 13 & 15.4 \\
Children & 12 & 14.2 \\
Spouse & 11 & 13.0 \\
Legal and personal representatives & 6 & 0.07 \\
Anyone else to act on their behalf & 6 & 0.07 \\
Assignees & 3 & 0.03 \\
Agents & 2 & 0.02 \\
All members of family & 1 & 0.01 \\
\hline
\end{tabular}

\section{Research Question 3: Are Risks Properly Communicated to Provide Informed Consent?}

The findings show that only two events had well-crafted waivers that clearly described the myriad of risks posed by triathlon participation. Most waivers were ambiguous or overly broad, providing no meaningful information to the participant about the specific risks. Therefore, the answer to Research Question 3 is that $97.6 \%(n=82)$ of the waivers did not provide specific notice of the various risks to establish that the participant knowingly accepted those risks.

Within the original 17 clauses, four categories included risks. Natural risks were defined as those risks that are possible on the course such as weather, water or road conditions, or other acts of God; 63 waivers included such items. Human risks, those caused by other people such as drivers, participants, volunteers, or paid event staff were identified in 60 waivers. Other harms that were waived identified the personal and economic injuries that could occur, with 72 waivers coded. These three categories were further analyzed to identify the specific risks or harms stated in the document and the frequency these specific risks or harms occurred within the waivers. Table 4 identifies the specific harms identified.

Many of the risks associated with participating in a triathlon are related to the triathlete's own fitness to compete. Sixty-seven (79.76\%) of the waivers included a clause that the triathlete warrants that he/she is in the physical condition necessary to complete the race and has not been instructed not to do so by a health care professional. While injury caused by lack of personal fitness for the event is not 
Table 4 Specific Harms Identified in the Waiver

\begin{tabular}{lcc}
\hline Coded Variable & $\boldsymbol{n}$ & $\%$ \\
\hline Death & 52 & 62.0 \\
Personal injury & 18 & 21.40 \\
Partial or permanent disability & 17 & 20.0 \\
All liability, injury, claims, losses damages, or cost. & 6 & 0.07 \\
Theft & 6 & 0.07 \\
Illness & 6 & 0.07 \\
Medical bills & 3 & 0.03 \\
Accidents & 3 & 0.03 \\
Equipment failure & 3 & 0.03 \\
Paralysis & 3 & 0.03 \\
Exposure to extreme conditions & 2 & 0.02 \\
Loss or damage to property & 2 & 0.02 \\
Contact or collision with other participants, spectators, vehi- & 2 & 0.02 \\
cles, or other objects & & \\
Imperfect course conditions & 2 & 0.02 \\
Any and all of his/her rights & 2 & 0.02 \\
Inadequate safety measures & 1 & 0.01 \\
Loss of wages & 1 & 0.01 \\
\hline
\end{tabular}

something that is within the control of the triathlon management, including this information helps the participant to more fully understand the significant physical demands of the event and may cause him or her to better consider whether to assume the risk of participating.

\section{Recommendations}

Given the poor overall quality of the participant waivers examined in this study, enforceability of the waivers and better information to make participants aware of the risks inherent in triathlons could be improved by incorporating several clauses in the document. In formatting the waiver, use of a title printed in boldface, headers, and 12-point font for easy visibility will clearly communicate the intent of the document (Hanks, 2005; Lewis, 2012). While risk communication may not successfully resolve all risks, neglecting to do so may lead to participants being exposed to harm unnecessarily (Goldstein, 2003; Slovic \& Peters, 2006). Triathlon organizers need to use plain, easily comprehendible language that provides notice that the waiver is a contract that shifts the liability for negligence from expressly named parties such as the owner of the event, landowners, sponsors, volunteers, and coparticipants to the triathlete participant (Hanks, 2005; Hyson v. White Water Mountain Resorts of Connecticut, Inc., 2003). Concise, yet specific, language should 
include the communication of the risks inherent in triathlon participation, including open water and open roads, nonparticipants on the course, and fitness to compete, and that the triathlete participant understands these risks and agrees to participate (Buchan, 1991; Okura, 1986). For events that are held in states that allow voluntary participants in sporting events to waive the rights of others, such as heirs and/or the estate, notice that these rights are waived by contract should the participant die as a result of participation should be clearly stated. Ideally, the document should fit on one page with nothing printed after the space for the participant's signature and date at the end of the waiver (Okura, 1986).

\section{Future Research}

This study found that triathlon waivers do a poor job of communicating the risks associated with triathlon participation. A future study could measure whether triathlon participants believe they are fully informed of the risks of competing, whether they knowingly appreciate and accept those risks, and what duty they have to other participants. Similarly, event managers could be surveyed to determine the process for constructing the participant waiver associated with their event; are they developing contracts unique to their event, using a document provided by their insurer, or simply adopting a waiver from another event or a standard form waiver from USA Triathlon? Another study could examine triathlon waivers state by state to determine whether the forms used conform to that particular state law. In addition, state legislation could be examined to determine language that must be contained in an enforceable liability waiver.

\section{Conclusion}

As participation waivers are contracts that shift liability from the event organizer to the participant, it is not surprising that triathlon organizers appear to be much more concerned with protecting themselves from liability than in informing participants of the risks inherent in the event. However, adequately informing participants of the dangers involved in triathlon participation could reduce injuries and harms that might occur, which would benefit both parties. Currently, waivers appear to allow triathlon organizers to be careless without risk of repercussions. The arguments that these documents should be unenforceable as against public policy are compelling. A document that fully communicates to the participant of the risks inherent in the activity would allow that triathlete to knowingly assume the risk. Assumption of risk is an adequate defense against negligence claims, therefore negating the need to waive the risk by contract. As long as states allow event organizers to shift liability through use of a participant waiver, uniform standards should be legislated to adequately inform participants of the risks and better protect them from harm.

\section{References}

Amburgey v. Atomic Ski, Inc., 2007 U.S. Dist. LEXIS 92762 (2007).

Andrew, D., Pedersen, P., \& McEvoy, C.D. (2011). Research Methods and Design in Sport Management. Champaign, IL: Human Kinetics. 
Angelo v. USA Triathlon, 2014 U.S. Dist. LEXIS 131759 (2014).

Atkins v. Swimwest Family Fitness Center, 277 Wis.2d 303 (2005).

Banfield v. Louis, 589 So.2d 441 (Fl. App. 1991).

Barron's Law Dictionary. (1991).

Berlangieri v. Running Elk Corp., 134 N.M. 341 (2003).

Black's Law Dictionary (1991).

Buchan v. U.S. Cycling Federation, 227 Cal. App. 3d 134 (1991).

Cabinetree of Wisconsin v. Kraftmaid Cabinetry, 50 F.3d 388, 1995 U.S. App. LEXIS 4244 ( $7^{\text {th }}$ Cir. Wis. 1995).

Calligeros, M. (2014). Mother at loss to explain healthy son's collapse. Retrieved from http:// www.brisbanetimes.com.au/queensland/triathlon-death-mother-at-loss-to-explainhealthy-sons-collapse-20140204-31yhv.html

Collinsworth, T. (2013). Injured Musselman rider dies. Finger Lakes Daily News. Retrieved from http://fingerlakesdailynews.com/news/details.cfm?id=86045\#.VD1YA9h0wdU

Conn. Rev. Stat. Ann. § 52-555a. Actions for loss of consortium re death of spouse independent for determination of damages (2014).

Conning v. Dietrich, 930 N.Y.S.3d 174 (2011).

Cotten, D.J. (1996). Guidelines for writing or evaluating exculpatory agreements. Journal of Legal Aspects of Sports, 6, 117-122.

Cotten, D.J. (2007). Waivers and releases. In D.J. Cotten \& J.T. Wolohan (Eds.), Law for Recreation and Sport Managers (4th ed., pp. 85-94). Dubuque, IA: Kendall/Hunt.

Coughlin v. T.M.H. International Attractions, 895 F.Supp. 159 (1995).

Creswell, L. (2013). Triathlon fatalities: 2013 in review. Retrieved from http://www.athletesheart.org/2013/12/triathlon-fatalities-2013-in-review

Dallam, G.M., Jonas, S., \& Miller, T.K. (2005). Medical considerations in triathlon competition: Recommendations for triathlon organisers, competitors and coaches. Sports Medicine (Auckland, N.Z.), 35, 143-161. doi:10.2165/00007256-200535020-00004

DeCuir-Gunby, J.T., Marshall, P.L., \& McCulloch, A.W. (2010). Developing and using a codebook for the analysis of interview data: An example from a professional development research project. Field Methods, 23, 136-155. doi:10.1177/1525822X10388468

Eriksson v. Nunnink, 233 Cal. App. 4th 708 (2015).

Espinoza, Jr., v. Arkansas Valley Adventures, LLC; 2014 U.S. Dist. LEXIS 136102

Ford, B. (2014). Are triathlon swims getting safer? Retrieved from http://espn.go.com/sports/ endurance/story/_/id/11169964/endurance-sports-safety-triathlon-swims-continuesissue-sport

Goldstein, B.D. (2005). Advances in risk assessment and communication. Annual Review of Public Health, 26, 141-163. doi:10.1146/annurev.publhealth.26.021304.144410

Greer, A. (2011), Extreme sports and extreme liability: The effect of waivers of liability in extreme sports. Retrieved from http://works.bepress.com/amanda_greer/1

Grieshop Corrada, S.M. (2006). Liability waivers in the United States travel and adventure sports industry. International Travel Law Journal, 2006, 156-161.

Haggerty, R., \& Held, T. (2009). Man who died in Pewaukee triathlon had lost 100 pounds in training. Milwaukee Journal Sentinel. Retrieved from http://www.jsonline.com/ news/waukesha/50617442.html

Hague v. Summit Acres Skilled Nursing \& Rehabilitation, 2010 Ohio App. LEXIS 5400 (2010).

Hanks v. Powder Ridge Restaurant Corp., 276 Conn. 314 (2005).

Harris, K.M., Henry, J.T., Rohman, E., Haas, T.S., \& Maron, B.J. (2010). Sudden death during the triathlon. Journal of the American Medical Association, 303(13), 1255-1257. doi:10.1001/jama.2010.368

Held, T. (2009, July 18). Big races mean big risks: More triathlons, more racers, have led to more fatalities. Retrieved from http://www.jsonline.com/features/health/51055267.html 
Henderson v. Quest Expeditions, 2005 Tenn. App. LEXIS 334 (June 8, 2005).

Hyson v. White Water Mountain Resorts of Connecticut, Inc., 265 Conn. 636 (2003).

Kolosnitsyn v. Crystal Mountain, Inc., 2009 U.S. Dist. LEXIS 79111 (2009).

Kubisen v. Chicago Health Clubs, 69 Ill. App. 3d 463 (1979).

Lashley v. East County Gymnastics, 2001 Cal.App. Unpub. LEXIS 1729 (2001).

Last v. Quail Valley Country Club, 2010 Tex. App. LEXIS 2303 (2010).

Lewis v. Habitat for Humanity of Greater New Haven, Inc., 2012 Conn. Super. LEXIS 146 (2012).

Macqueen, K.M., McLellan, E., Kay, K., \& Milstein, B. (1998). Codebook development for team-based qualitative analysis. Cultural Anthropology Methods, 10, 31-36.

Marron, B.J., Araujo, C.G., Thompson, P.D., Fletcher, G.F., de Luna, A.B., Fleg, J.L., . . . Bazzarre, T.L. (2001). Recommendations for preparticipation screening and the assessment of cardiovascular disease in masters athletes: an advisory for healthcare professionals from the working groups of the World Heart Federation, the International Federation of Sports Medicine, and the Am Heart Association Committee on Exercise, Cardiac Rehabilitation, and Prevention. Circulation, 103, 327-334. doi:10.1161/01.CIR.103.2.327

McDonald v. Whitewater Challengers, Inc., 2015 PA Super 104, 2015 Pa. Super. LEXIS 232 (Pa. Super. Ct. 2015).

Mero v. City Segway Tours of Washington, DC, LLC, 962 F. Supp. 2 d 92 (D.D.C. 2013).

Miller, J., Pauline, G \& Wendt, J. T. (2014). An investigation of risk management protocols at triathlon events. Journal of Event and Venue Management, 4(2). Retrieved from http://sc.edu/study/colleges_schools/hrsm/research/journal_venue_and_event_management_archives/jvem_pdfs/vol4_no2/investigation_of_risk_management_protocols.pdf.

Miller, J., Young, S., \& Martin, N. (2009). To use or not to use? The status of waivers in intramural sports. Recreational Sports Journal, 33(2), 129-138.

Moore v. North American Sports, Inc., 2008 U.S. Dist. LEXIS 102437 (2008).

Moser v. Ratinoff, 105 Cal. App. $4^{\text {th }} 1211$ (2003).

Okura v. U.S. Cycling Federation, 186 Cal.App.3d 1462 (1986).

Palmer v. Lakeside Wellness Ctr., 281 Neb. 780 (2011).

Restatement 2d. of Contracts, $\$ 195$ (1981).

Reynolds, B., \& Seeger, M.W. (2005). Crisis and emergency risk communication as an integrative model. Journal of Health Communication, 10, 43-55. doi:10.1080/10810730590904571

Roer v. 150 West End Avenue Owners Corp., 2010 N.Y. Misc. LEXIS 6353 (2010).

Rustad, M.L., Buckingham, R., D’Angelo, D., \& Durlacher, K. (2012). An empirical study of predispute mandatory arbitration clauses in social media terms of service. University of Arkansas Little Rock Law Review, 34, 643-683.

Sa v. Red Frog Events, LLC, 2013 U.S. Dist. LEXIS 151355 (2013).

Schmidt v. Midwest Sports Events, Inc., Complaint and Jury Demand, No. 2010-CV-1509, 2010 WL 8453207 (Wis.Cir. August 4, 2010).

Schmidt v. Midwest Sports Events, Inc., No. 2010-CV- 1509, 2012 WL 1964476 (Wis. Cir. Jan. 3, 2012).

Schoeps v. Whitewater Adventures LLC, 136 Fed. Appx. 966 (2005).

Slovic, P., \& Peters, E. (2006). Risk perception and affect. Psychological Science, 15(6), $322-325$.

Triathlete.com. (2013). Two die at 70.3 South Africa. Retrieved from http://triathlon.competitor.com/2013/01/news/two-die-at-70-3-south-africa_69543

Triathlete.com. (2014). Man died during his triathlon in Naples Florida. Retrieved from http://triathlon.competitor.com/2014/01/news/man-dies-during-hits-triathlon-in-naplesflorida_92545

Triathlon, U.S.A. (2014). 2013 USA Triathlon Membership Report. Retrieved from http:// www.usatriathlon.org/about-multisport/demographics.aspx 
Triathlon, U.S.A. (2014A). NCAA Division I Legislative Council Approves Triathlon as Emerging Sport. Retrieved from http://www.usatriathlon.org/news/ articles/2014/1/011614-ncaa-announcement.aspx

Tunkl v. Regents of the University of California, 60 Cal.2d 92 (1963).

Wycoff v. Grace Community Church of the Assemblies of God, 251 P.3d 1260 (2010).

Young, S.J. (2001). A content analysis of legal aspects courses in sport management. Journal of Legal Aspects of Sport, 11, 225-243. 